\title{
Rectal absorption of diazepam in epileptic children
}

\author{
SORAYA DHILLON, EUGENIA NGWANE, AND ALAN RICHENS
}

Park Hospital for Children, Oxford, and Department of Pharmacology and Materia Medica, Welsh National School of Medicine, Cardiff

SUMMARY The absorption of diazepam after rectal administration was studied in children with epilepsy. When given as a solution, diazepam was rapidly absorbed and produced serum diazepam concentrations above $200 \mathrm{ng} / \mathrm{ml}$ within 10 minutes in most children. However, a commercial suppository formulation was absorbed slowly and cannot be recommended for urgent treatment of fits. There is a need in the UK for a rapidly absorbed preparation of diazepam which is approved for rectal use.

Fits are a common problem in paediatric practice; before age 5 years between 7 and $8 \%$ of children will each have had at least one febrile or nonfebrile fit. ${ }^{1}$ Prolonged fits in young children are known to be damaging to the brain, in particular to the temporal lobes, and may lead to chronic epilepsy. ${ }^{2}$ Urgent treatment is therefore essential. Although intravenous diazepam is the drug of choice to terminate a prolonged fit or status epilepticus, this route of administration is impractical if the fit occurs at home.

Intramuscular diazepam is erratically absorbed, ${ }^{34}$ and this route is not satisfactory for immediate treatment. Rectal administration of diazepam suppositories results in low plasma levels attained after delays of up to 2 hours. ${ }^{56}$ However, rectal administration of diazepam solution leads to rapid absorption with peak plasma levels within 10 minutes, ${ }^{7}$ and this form of treatment has been recommended for home use $;^{8}$ however no such preparation is marketed in the UK. We report a comparison of the absorption of diazepam in children after administration as a solution or a suppository.

\section{Patients and methods}

Thirteen epileptic children aged between 1 and 15 years were studied. They had been admitted to the John Radcliffe Hospital, Oxford, for assessment for a ketogenic diet for the control of intractable seizures. They were regularly receiving a variety of antiepileptic drugs - such as phenytoin, phenobarbitone, carbamazepine, sodium valproate, and clonazepam. Informed consent was obtained from the parents, and the study was approved by the local ethical committee. Diazepam was administered electively to assess the absorption of the drug in rectal solution or suppository so as to assess the future use of such modes of treatment at home.

The following preparations were used: Valium (Roche) solution for intravenous administration (10 mg/2 ml) and Stesolid (Dumex, Copenhagen) suppository $(5 \mathrm{mg}$ and $10 \mathrm{mg})$. The children were

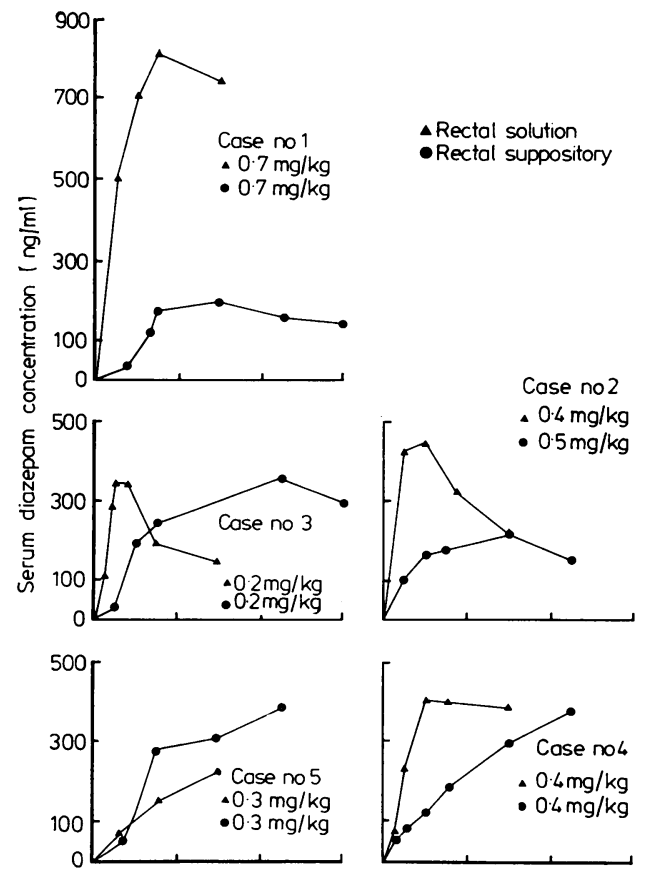

Fig. 1 Individual serum diazepam concentration profiles in 5 children after rectal solution or rectal suppository. 
fasted for 24 hours for establishment of the ketogenic diet, and diazepam was administered in the morning of each test day. No bowel preparation was used. Five children received in a random order either rectal diazepam solution or suppository in a dose of $0 \cdot 2-0.7 \mathrm{mg} / \mathrm{kg}$. After an interval of at least 48 hours the alternative preparation was given to each.

Eight additional unselected children received only one preparation. Diazepam solution was administered using a plastic syringe fitted with a soft polyethylene catheter $10-12 \mathrm{~cm}$ in length. The dead space in the catheter was allowed for so that the correct dose of drug was instilled into the rectum. The suppository was inserted manually to one digit length.

Clotted blood samples, of $1 \mathrm{ml}$, were taken using an indwelling butterfly needle at the following times: before drug administration, then 5, 10, 20, 30 , and 60 minutes after rectal solution, and at 0 , $10,20,30,60,90$, and 120 minutes after the suppository formulation. Determination of diazepam in serum was performed by gas liquid chromatography. ${ }^{9}$

\section{Results}

Within-subject comparison. Fig. 1 shows the serum diazepam concentration profile in each of the 5 children who received both preparations. Diazepam solution was rapidly absorbed in 4 of them, aged 1-9 years, peak serum concentrations of $350-800$ $\mathrm{ng} / \mathrm{ml}$ being attained within 10-30 minutes. The absorption after administration of the suppository was slower, and peak serum levels were obtained after delays of $60-90$ minutes in 3 children. One 15-year-old child (Case 5) showed a slow rate of absorption after administration of the rectal solution. Peak serum concentration was not achieved within 60 minutes. Table 1 (upper half) shows the serum concentration at 10 minutes in these 5 children. In 4 of them the serum concentration at 10 minutes was much higher after rectal administration of diazepam in solution than after the suppository.

All subjects. Fig. 2 shows the serum concentration profiles of diazepam after rectal administration of diazepam solution in each child. Peak serum

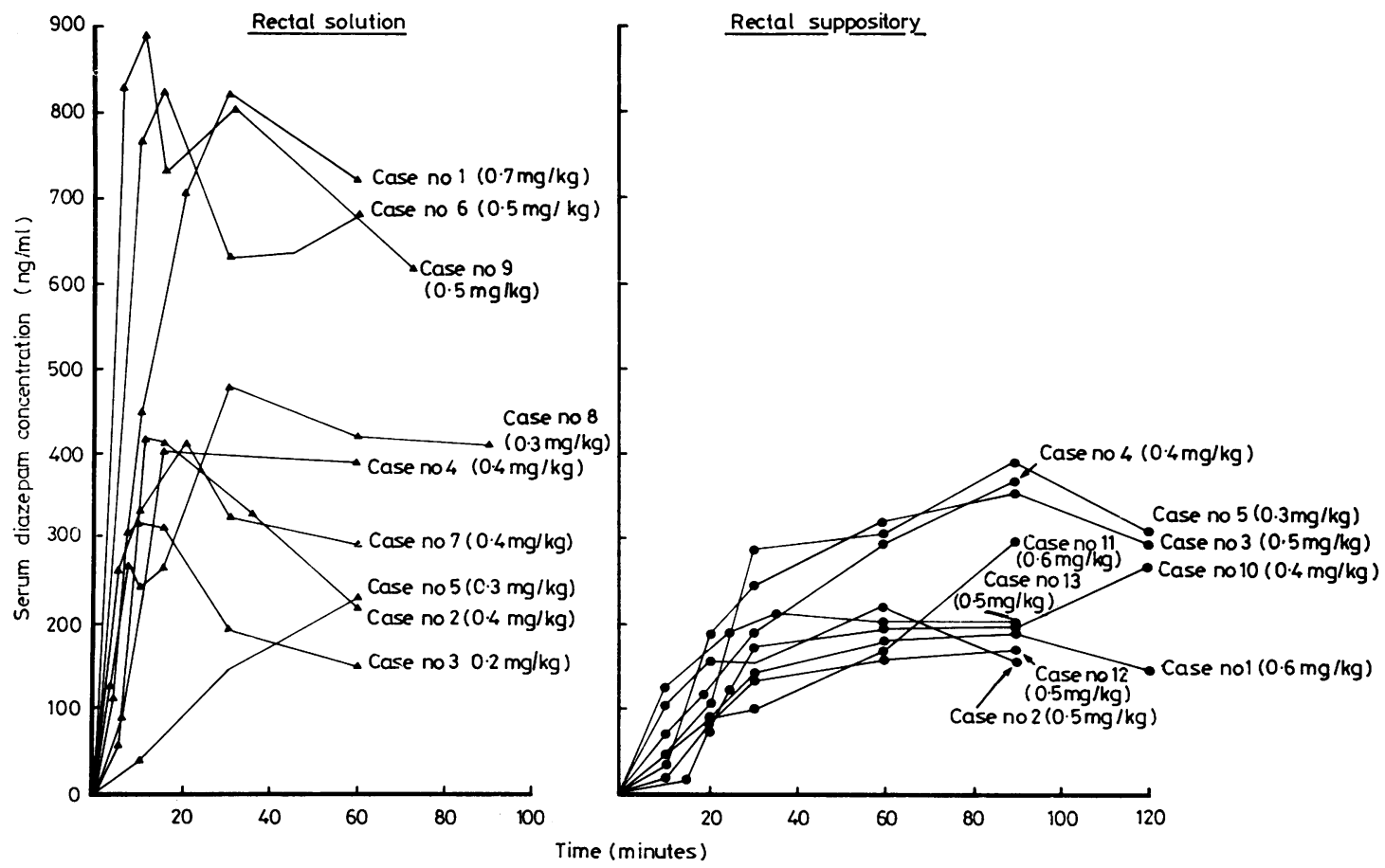

Fig. 2 Individual serum diazepam concentration profiles in all children after rectal solution or rectal suppository. 
Table Serum diazepam concentrations 10 minutes after rectal administration of diazepam solution and suppository

\begin{tabular}{|c|c|c|c|c|c|c|c|c|c|}
\hline \multirow[t]{2}{*}{ Case } & \multirow{2}{*}{$\begin{array}{l}\text { Age } \\
\text { (years) }\end{array}$} & \multirow{2}{*}{$\begin{array}{l}\text { Weight } \\
(k g)\end{array}$} & \multicolumn{2}{|l|}{ Solution } & \multirow[t]{2}{*}{ Case } & \multirow{2}{*}{$\begin{array}{l}\text { Age } \\
\text { (years) }\end{array}$} & \multirow{2}{*}{$\begin{array}{l}\text { Weight } \\
(k g)\end{array}$} & \multicolumn{2}{|c|}{ Suppository } \\
\hline & & & $\begin{array}{l}\text { Dose } \\
(m g / k g)\end{array}$ & $\begin{array}{l}\text { Serum } \\
\text { diazepam } \\
\text { concentrations } \\
(\mathrm{ng} / \mathrm{ml})\end{array}$ & & & & $\begin{array}{l}\text { Dose } \\
(m g / k g)\end{array}$ & $\begin{array}{l}\text { Serum } \\
\text { diazepam } \\
\text { concentrations } \\
(n g / m l)\end{array}$ \\
\hline $\begin{array}{l}1 \\
2 \\
3 \\
4 \\
5 \\
6 \\
7 \\
8 \\
9\end{array}$ & $\begin{array}{r}1 \cdot 4 \\
2 \cdot 2 \\
6 \cdot 0 \\
9 \cdot 5 \\
15 \cdot 2 \\
7 \cdot 2 \\
7 \cdot 8 \\
10 \cdot 9 \\
5 \cdot 9\end{array}$ & $\begin{array}{r}7 \\
12 \\
21 \\
21 \\
65 \\
21 \\
26 \\
48 \\
18\end{array}$ & $\begin{array}{l}0.7 \\
0.4 \\
0.2 \\
0.4 \\
0.3 \\
0.4 \\
0.4 \\
0.3 \\
0.5\end{array}$ & $\begin{array}{r}450 \\
420 \\
325 \\
235 \\
38 \\
770 \\
330 \\
240 \\
830\end{array}$ & $\begin{array}{r}1 \\
2 \\
3 \\
4 \\
5 \\
10 \\
11 \\
12 \\
13\end{array}$ & $\begin{array}{r}1 \cdot 4 \\
2 \cdot 2 \\
6 \cdot 0 \\
9 \cdot 5 \\
15 \cdot 2 \\
3 \cdot 2 \\
4 \cdot 3 \\
8 \cdot 4 \\
9 \cdot 0\end{array}$ & $\begin{array}{r}7 \\
12 \\
21 \\
21 \\
65 \\
16 \\
15 \\
20 \\
20\end{array}$ & $\begin{array}{l}0.6 \\
0.4 \\
0.5 \\
0.4 \\
0.3 \\
0.6 \\
0.6 \\
0.5 \\
0.5\end{array}$ & $\begin{array}{r}35 \\
100 \\
31 \\
81 \\
50 \\
27 \\
52 \\
26 \\
121\end{array}$ \\
\hline $\begin{array}{l}\text { Mean } \\
\text { SD }\end{array}$ & & & $\begin{array}{l}0.40 \\
0 \cdot 14\end{array}$ & $\begin{array}{l}404^{*} \\
255\end{array}$ & & & & $\begin{array}{l}0.48 \\
0 \cdot 11\end{array}$ & 58 \\
\hline
\end{tabular}

*P $<0.002$ Mann-Whitney $U$ test.

concentrations were achieved in all but one within 30 minutes and, with the exception of Case 3, who received only $0.2 \mathrm{mg} / \mathrm{kg}$, serum levels remained above $200 \mathrm{ng} / \mathrm{ml}$ for up to 60 minutes. Serum diazepam concentrations after the suppository formulation (Fig. 2) appeared to peak 60-120 minutes after the insertion of the suppository in some of them, but the duration of sampling was not long enough to show the peak in others. The rate of absorption after this route of administration was clearly slower than after the rectal solution.

The Table compares the serum diazepam concentration at 10 minutes after each of the two dosage forms. The mean dose administered in suppository form was slightly greater than that administered in solution. Despite this the serum diazepam concentration at 10 minutes was significantly higher in the children receiving the solution.

\section{Discussion}

Diazepam administered rectally as a solution is absorbed faster than when given as a suppository. Peak serum levels of only $210-390 \mathrm{ng} / \mathrm{ml}$ were attained after delays of $60-90$ minutes in the majority of patients receiving the suppository.

Information is limited on the serum concentration of diazepam that needs to be achieved for an effective anticonvulsant action to be seen. Data ${ }^{10} 11$ suggest that serum levels of between 150 and $300 \mathrm{ng} / \mathrm{ml}$ are required. Our results show that in all but one child levels above $150 \mathrm{ng} / \mathrm{ml}$ were attained within 10 minutes after rectal solution, whereas delays of up to 60 minutes were observed with the suppository. Our findings agree with those of others ${ }^{712} 13$ and indicate that this route of administration and dosage form may be an effective alternative to intravenous administration in treating seizures in children.

However, there is no dosage form available in the UK which is marketed for rectal use. In the data sheet for Valium Roche no mention is made of rectal use and indeed this has not been approved by the Committee on Safety of Medicines. Nevertheless, mothers have been instructed to use Valium ampoules, drawing-up the drug with a needle and syringe and then administering the solution by placing the barrel of the syringe directly into the rectum or by attaching a soft polyethylene catheter to the syringe. ${ }^{8}$ No toxicological consequence of this practice has so far been reported, although solutions for rectal use have been available for several years in Scandinavian countries: Apozepam and Vival ampoules for rectal use (Apothekernes Laboratorium for Specialpraeparater) and Stesolid rectal tubes (Dumex).

Administration of a solution can present problems for a distressed mother faced with a convulsing infant. Suppositories are therefore a more convenient dosage form but of those preparations commercially available in Europe (Stesolid Dumex; Valium Roche) both have the major disadvantage of a slow rate of absorption and are therefore unsatisfactory for use in an emergency. ${ }^{612}$

Advances in the manufacture of suppository formulations are likely to lead to the development of rapidly absorbed suppositories, but until these become available, the use of rectal solution administered in the manner outlined by Bower ${ }^{8}$ is a realistic alternative.

\footnotetext{
References

1 Munthe-Kaas A W. Cited in Lennox-Buchthal M A. Febrile convulsions. Electroencephalogra Clin Neurophysiol [Suppl] 1973; Supplement 32, 111.
} 
2 Brown J K. Fits in childhood. In: Laidlaw J, Richens A, eds. A textbook of epilepsy. Edinburgh: Churchill Livingstone, 1976: 66.

3 Langslet A, Meberg A, Bredesen J E, Lunde P K M. Plasma concentrations of diazepam and $N$-desmethyldiazepam in newborn infants after intravenous, intramuscular, rectal, and oral administration. Acta Paediatr Scand 1978; 67: 699-704.

4 Meberg A, Langslet A, Bredesen J E, Lunde P K M. Plasma concentration of diazepam and $N$-desmethyldiazepam in children after a single rectal or intramuscular dose of diazepam. Eur J Clin Pharmacol 1978; 14: 273-6.

5 Arnold E. A simple method for determining diazepam and its major metabolites in biological fluids: application in bioavailability studies. Acta Pharmacol Toxicol (Copenh) 1973; 36: 335-52.

- Schwartz D E, Vecchi M, Ronco A, Kauser K. Blood levels after administration of 7-chloro-13 dihydro-1 methyl-5 phenyl 2H, 1, 4 benzodiazepine 2 one (diazepam) in various forms. Arzneim Forsch 1966; 16: 1109-10.

7 Agurell S, Berlin A, Ferngren H, Hellström B. Plasma levels of diazepam after parenteral and rectal administration in children. Epilepsia $1975 ; 16: 277-83$.

8 Bower B D. The treatment of epilepsy in children. Br J Hosp Med 1978; 19 : 8-19.
9 Rutherford D M. Rapid micromethod for the measurement of diazepam and desmethyldiazepam in blood plasma by gas liquid chromatography. J Chromatogr 1977; 137: 439-48.

10 Viala A, Cano J P, Dravet C, Tassinari C A, Roger J. Blood levels of diazepam (Valium) and $N$-desmethyldiazepam in the epileptic child. A preliminary report. Psychiatr Neurol Neurochirurgie 1971; 74: 153-8.

11 Ferngren H G. Diazepam treatment for acute convulsions in children. Epilepsia 1974; 15 : 27-37.

12 Knudsen F U. Plasma-diazepam in infants after rectal administration in solution and by suppository. Acta Paediatr Scand 1977; 66: 563-7.

13 Dulac O, Aicardi J, Rey E, Olive G. Blood levels of diazepam after single rectal administration in infants and children. J Pediatr 1978; 93: 1039-41.

Correspondence to Dr S Dhillon, Welsh National School of Medicine, Department of Pharmacology and Materia Medica, Heath Park, Cardiff CF4 4XN.

Received 6 August 1981 